\title{
Comparative Study of Strategic Supplementation on Enhancement of Average Milk Production of Cattle
}

\author{
Vivekin Pachuari $^{1 *}$, Sushil Kumar Mishra ${ }^{2}$, A.K. Tripathi ${ }^{1}$ and K.S. Yadav $^{3}$ \\ ${ }^{3}$ Horticulture, ${ }^{1}$ Krishi Vigyan Kenra, Sagar, JNKVV, Jabalpur, India \\ ${ }^{2}$ DHRTC, Garhakota, JNKVV, Jabalpur, India \\ *Corresponding author
}

\section{A B S T R A C T}

\section{Keywords \\ Strategic \\ Supplementation, \\ Cattle, Feed, \\ Fodder, Parity, \\ Stage of Lactation \\ Article Info \\ Accepted: \\ 15 April 2019 \\ Available Online: \\ 10 May 2019}

The present study was conducted to ascertain the effects of feeding Strategic supplementation. The trial was conducted on 40 lactating cows on villages of Jasinagar road of district Sagar, Madhya Pradesh. Cows were divided randomly into 4 dietary treatments of 10 animals each considering their body weight, milk yield, parity and stage of lactation. The experiment was conducted for the period of 180 days. In group I (control group) the average milk yield of the animals was $4.42 \pm 0.28$. In group II, the average milk yield was $4.23 \pm 0.73$. The variation between the milk yield of the group I and group II before the experiment was 0.19 litre. In group III, the average milk yield of the animals was $4.88 \pm 1.03$ litre. The variation between the milk yield of group I and group III before the start of experiment was 0.46 litre. In group IV the average milk yield of the animals before the start of experiment was $4.96 \pm 1.31$ litre. The variation between the milk yield of group I and IV before the experiment was 0.54 litre it was maximum among the entire three groups.

\section{Introduction}

In recent years, there has been a considerable interest in the technological interventions for enhanced livestock productivity in the Indian sub- continent, because of the increased demand for livestock products for human consumption. In India management of cows and buffaloes in villages is very poor. For the process of economic development, it is necessary that production functions should increase with the increase in milk production. Feeds and fodders are the most important inputs for milk production. About two third of the total cost of milk production is covered by the cost of feed and fodders alone (Anil Kumar and Rai, 2008) productivity potential of our livestock has not been fully exploited because of deficit feed resources and under utilization of available technologies to fill the deficiency of nutrients in their ration. For achieving the economic productivity in livestock, it is essential to enhance the feeding value of available feed resources, particularly the crop residues. The fibrous crop residues must be used in the ration of growing animals in such a way that could provide required amount of energy, protein and minerals as per 
their nutritional requirement. There is a shortage of quality feed and fodders in India, which appears to continue in near future. Crop residues available with most of farmers, are utilized to feed the animals round the year. These fibrous crop residues, deficient in protein, energy and minerals, have poor palatability and digestibility and need supplementation for their proper utilization. Minerals that are not sufficient from feed and fodders ingested by animals only need to be supplemented through mineral mixture. Effect of diet on eating pattern and milk composition of lactating animals has been reported by various workers (Heinriches and Conrad, 1987; Senn et al., 1995). In view of above the present study was undertaken to assess the effect of strategic supplementation on milk production of cattle.

\section{Materials and Methods}

The present study was conducted on 40 lactating cows of the second to third lactation were selected individually from villages baddaua, semadhana, baroda, sallaiyagazi, hinnpur, gosra and kakarkuiya situated as jaisinagar road of district sagar, Madhya Pradesh. Cows were divided randomly into 4 dietary treatments of 10 animals each considering their body weight, milk yield, parity and stage of lactation. The experiment was conducted for the period of 180 days.

\section{Dietary treatment}

The four dietary treatment used are as under

\section{Group I ( $\left.\mathbf{T}_{1}\right)$}

Group I will be control. The animals were be fed diet regularly used in the farmer's field. It will consist of wheat straw adlib and in addition to that green Berseem is provided daily in the evening while concentrate mixture will be provided at the time of milking daily in the morning and evening.

\section{Group II ( $\left.\mathbf{T}_{2}\right)$}

The animals of this group were be fed similar diet to control but it will be supplemented with mineral mixture @ 2\% of the diet.

\section{Group III ( $\left.\mathbf{T}_{3}\right)$}

The animals of this group were be maintained on strategic supplementation. The diet will be given exactly as per their nutrient requirement.

\section{Group IV ( $\left.\mathbf{T}_{4}\right)$}

The animals of this group were be fed similar to diet as group III with addition of mineral supplementation.

\section{Statistical analysis}

The data obtained were analyzed using general statistics viz., computation of percentage, mean, standard deviation and correlation coefficient. Two sample test for mean and proportion on normal distribution and one way ANOVA was used to find significant differences among groups.

\section{Results and Discussion}

\section{Feeding practices existing in the dairy farm}

In all the lactating cows ad lib feeding of straw was practiced. The preferred straw used for the feeding of animals was wheat straw. Besides wheat straw limited quantity of green Berseem was offered daily to each cow.

\section{Milk production of the animals}

Milk yield was recorded on fortnightly basis and average milk yield of the animals before the start of experiment is presented in Table $1-3$. 
Table.1 Average milk production of animals on fortnightly basis before supplementation

\begin{tabular}{|c|c|c|c|c|c|c|c|c|}
\hline \multirow[b]{2}{*}{ S. No } & \multicolumn{2}{|l|}{ Group I } & \multicolumn{2}{|c|}{ Group II } & \multicolumn{2}{|c|}{ Group III } & \multicolumn{2}{|c|}{ Group IV } \\
\hline & $\begin{array}{c}\text { Animal } \\
\text { No. }\end{array}$ & $\begin{array}{c}\text { Milk } \\
\text { production } \\
\text { (Lit.) }\end{array}$ & $\begin{array}{c}\text { Animal } \\
\text { No. }\end{array}$ & $\begin{array}{c}\text { Milk } \\
\text { production } \\
\text { (Lit.) }\end{array}$ & $\begin{array}{c}\text { Animal } \\
\text { No. }\end{array}$ & $\begin{array}{c}\text { Milk } \\
\text { production } \\
\text { (Lit.) }\end{array}$ & $\begin{array}{c}\text { Animal } \\
\text { No. }\end{array}$ & $\begin{array}{c}\text { Milk } \\
\text { production } \\
\text { (Lit.) }\end{array}$ \\
\hline 1 & A1 & 4.52 & B1 & 5.20 & C1 & 4.30 & D1 & 5.80 \\
\hline 2 & A2 & 6.26 & B2 & 4.85 & $\mathrm{C} 2$ & 5.65 & D2 & 6.30 \\
\hline 3 & A3 & 4.43 & B3 & 3.25 & C3 & 3.65 & D3 & 3.85 \\
\hline 4 & A4 & 4.30 & B4 & 3.80 & C4 & 5.20 & D4 & 3.35 \\
\hline 5 & A5 & 3.52 & B5 & 3.52 & C5 & 6.40 & D5 & 3.55 \\
\hline 6 & A6 & 5.20 & B6 & 4.60 & C6 & 6.22 & D6 & 4.80 \\
\hline 7 & A7 & 3.60 & B7 & 4.50 & C7 & 5.15 & D7 & 6.50 \\
\hline 8 & A8 & 3.24 & B8 & 5.25 & C8 & 4.80 & D8 & 6.85 \\
\hline 9 & A9 & 4.90 & B9 & 3.60 & C9 & 4.25 & D9 & 3.89 \\
\hline 10 & A10 & 4.25 & B10 & 3.75 & $\mathrm{C10}$ & 3.27 & D10 & 4.80 \\
\hline Mean & - & 4.42 & - & 4.23 & - & 4.88 & - & 4.96 \\
\hline SE & - & 0.08 & - & 0.23 & - & 0.33 & - & 0.41 \\
\hline SD & - & 0.28 & - & 0.73 & - & 1.03 & - & 1.31 \\
\hline
\end{tabular}

Table.2 Average milk production of animals on fortnightly basis after supplementation

\begin{tabular}{|c|c|c|c|c|c|c|c|c|}
\hline S. No & \multicolumn{2}{|c|}{ Group I } & \multicolumn{2}{|c|}{ Group II } & \multicolumn{2}{|c|}{ Group III } & \multicolumn{2}{c|}{ Group IV } \\
\hline & $\begin{array}{c}\text { Animal } \\
\text { No. }\end{array}$ & $\begin{array}{c}\text { Milk } \\
\text { production } \\
\text { (Lit.) }\end{array}$ & $\begin{array}{c}\text { Animal } \\
\text { No. }\end{array}$ & $\begin{array}{c}\text { Milk } \\
\text { production } \\
\text { (Lit.) }\end{array}$ & $\begin{array}{c}\text { Animal } \\
\text { No. }\end{array}$ & $\begin{array}{c}\text { Milk } \\
\text { production } \\
\text { (Lit.) }\end{array}$ & $\begin{array}{c}\text { Animal } \\
\text { No. }\end{array}$ & $\begin{array}{c}\text { Milk } \\
\text { production } \\
\text { (Lit.) }\end{array}$ \\
\hline 1 & A1 & 4.78 & B1 & 7.20 & C1 & 3.50 & D1 & 6.25 \\
\hline 2 & A2 & 6.48 & B2 & 4.50 & C2 & 4.25 & D2 & 5.55 \\
\hline 3 & A3 & 4.68 & B3 & 4.50 & C3 & 4.55 & D3 & 5.25 \\
\hline 4 & A4 & 4.35 & B4 & 3.20 & C4 & 3.50 & D4 & 4.85 \\
\hline 5 & A5 & 3.72 & B5 & 4.25 & C5 & 6.80 & D5 & 4.50 \\
\hline 6 & A6 & 5.35 & B6 & 5.50 & C6 & 5.25 & D6 & 5.60 \\
\hline 7 & A7 & 3.78 & B7 & 3.25 & C7 & 6.85 & D7 & 7.80 \\
\hline 8 & A8 & 3.47 & B8 & 7.20 & C8 & 5.50 & D8 & 6.20 \\
\hline 9 & A9 & 4.59 & B9 & 4.57 & C9 & 6.20 & D9 & 4.70 \\
\hline 10 & A10 & 4.58 & B10 & 4.80 & C10 & 4.25 & D10 & 5.60 \\
\hline Mean & - & 4.57 & - & 4.89 & - & 5.06 & - & 5.63 \\
\hline SE & - & 0.27 & - & 0.43 & - & 0.40 & - & 0.30 \\
\hline SD & - & 0.87 & - & 1.39 & - & 1.25 & - & 0.96 \\
\hline
\end{tabular}


Table.3 Change in milk production of animals during experimental period

\begin{tabular}{|c|c|c|c|c|c|c|c|c|}
\hline S.No & Group I & \multicolumn{2}{|c|}{ Group II } & \multicolumn{2}{|c|}{ Group III } & \multicolumn{2}{|c|}{ Group IV } \\
\cline { 2 - 9 } & $\begin{array}{c}\text { Animal } \\
\text { No. }\end{array}$ & $\begin{array}{c}\text { Milk } \\
\text { production } \\
\text { (Lit.) }\end{array}$ & Animal No. & $\begin{array}{c}\text { Milk } \\
\text { production } \\
\text { (Lit.) }\end{array}$ & $\begin{array}{c}\text { Animal } \\
\text { No. }\end{array}$ & $\begin{array}{c}\text { Milk } \\
\text { production } \\
\text { (Lit.) }\end{array}$ & $\begin{array}{c}\text { Animal } \\
\text { No. }\end{array}$ & $\begin{array}{c}\text { Milk production } \\
\text { (Lit.) }\end{array}$ \\
\hline 1 & A1 & 0.26 & B1 & 2.00 & C1 & -0.80 & D1 & 0.45 \\
\hline 2 & A2 & 0.22 & B2 & -0.35 & C2 & -1.40 & D2 & -0.75 \\
\hline 3 & A3 & 0.25 & B3 & 1.25 & C3 & 0.90 & D3 & 1.40 \\
\hline 4 & A4 & 0.05 & B4 & -0.60 & C4 & -1.70 & D4 & 1.50 \\
\hline 5 & A5 & 0.20 & B5 & 0.73 & C5 & 0.40 & D5 & 0.95 \\
\hline 6 & A6 & 0.15 & B6 & 0.90 & C6 & -0.97 & D6 & 0.80 \\
\hline 7 & A7 & 0.18 & B7 & -1.25 & C7 & 1.70 & D7 & 1.30 \\
\hline 8 & A8 & 0.23 & B8 & 1.95 & C8 & 0.70 & D8 & -0.65 \\
\hline 9 & A9 & -0.31 & B9 & 0.97 & C9 & 1.95 & D9 & 0.81 \\
\hline 10 & A10 & 0.33 & B10 & 1.05 & C10 & 0.98 & D10 & 0.80 \\
\hline Mea & - & 0.15 & - & 0.66 & - & 0.18 & - & 0.66 \\
\hline n & & & & & & & & \\
\hline
\end{tabular}

In group I (control group) the average milk yield of the animals was $4.42 \pm 0.28$. In group II, the average milk yield was $4.23 \pm 0.73$. The variation between the milk yield of the group I and group II before the experiment was 0.19 litre. In group III, the average milk yield of the animals was $4.88 \pm 1.03$ litre.

The variation between the milk yield of group I and group III before the start of experiment was 0.46 litre. In group IV the average milk yield of the animals before the start of experiment was $4.96 \pm 1.31$ litre. The variation between the milk yield of group I and IV before the experiment was 0.54 litre it was maximum among the entire three groups. The average milk production recorded before the start of experiment is presented in table 1 .

\section{Milk yield}

Average change in milk production in animals in group I, II, III and IV respectively during the entire period of 180 days was $0.15,0.66$, 0.18 and $0.66 \mathrm{lit} /$ day which was very nominal of calculated on daily basis. Thus, change in feeding schedule by strategic supplementation showed an influence on the milk production of animals when compared with the feeding regime prevailing in the field.

It was in agreement with the work done by Sprowson, Holness (1980), Bae et al., (1994), Su and Hseih (1999), Rafiq et al., (2000) and Koval et al., (1983)

Chen et al., (1999) they reported higher average milk yield and its composition in cows fed with complete feed than in cows fed on conventional feed. Feeding of UMMB improved milk yield and composition both in buffalo and cows, the result were in agreement with the earlier study by Chauhan et al., (1997) and Ghebrehiwet et al., (1994) and Kunju (1986).

On the other hand Nocek et al., (1985), Patil et al., (1997), Ghosh et al., (2002) and Vijchulata et al., (1994) could not find any effect on milk yield of dairy cows fed on conventional ration and total mixed ration. 


\section{References}

Anil kumar and D.C.Rai 2008. Cost and returns from milk production in Faizabad district of Uttar Pradesh. Indian J. Anim. Nutr., 25(4): 369-372

Bae, O.H., C.N. Shin and K.H. Ko. 1994. Effect of total mixed ration including apple pomace for lactating cows. Korean J. Dainy Sci., 16: 295-302.

Chauhan, T.R., R. Gupta, S.S. Dahiya and B.S. Punia 1997. Effect of supplementing urea molasses blocks in the ration of buffaloes on nutrient utilization and milk production. Indian J. Anim. Sci. 67: 418-421.

Chen, J., Ren, M.Q., Meng, J., Qin, Y.O., Han, C.K., Giang, W.Q. and Shvai, W.B. 1990. Effect of sodium Acetate on Physiological Characteristics and Lactating Performance of Dairy Cows in Summer. Nutr. Abstr. Rev. (B), 60: 925.

Ghebrehiwet, T., M.N.M. Ibrahim and J.B. Schiere 1988/ 1994. Response of growing bulls to diets containing untreated or urea treated rice straw with rice bran supplementation. Biolog. Wastes. 25: 269-280.

Ghosh, T.K., Haldar, S. and Sarkar, J. 2002. Effect of Mineral Supplementation on Bioavailability of Organic Nutrients in Commercial Dairy Herds. Indian J. Anim. Sci. (Accepted for Publication).

Heinrichs, A.J., and H.R. Conrad.1987. Measuring feed intake patterns and meal size of lactating dairy cows. J. Dairy Sci. 70: 705-711.

Koval M.P., Balamut N.I., Mishanill Y.F., Tvardouskii A.D., Baranov N.N., Bugakov A.B. and Buzuk B.V., 1983. Metabolism of substances and productivity of cows on diet supplemented with trace elements. Nutrition Abstract and Review (B) 53: 215.
Kundu,S.S., A. K. Mishra and Pathak (Ed). 2004. Buffalo production under different climatic conditions. IBDC, Lucknow, U.P. India.

Kunju, P.J.G. 1986. Urea molasses block lick: a feed supplements for ruminants. In rice straw and related feeds in ruminants rations (M.N.M.) Ibrahim and J.B. (Scheiere). Proc. Workshop, Kandy, Srilanka (1986) pp. 261-74.

Nocek, J.E, R.L. Steele and D.G. Braund 1985. Performance of dairy cows fed forage and grain separately versus a total mixed ration. Journal of Dainy Science. 69: 2140-47.

Patil, C.N., Kank, V.D., Patil, M.B.; Karkhanis, S.S.; Puntambekar, P.M. and Hoi, A.G. 1997. Effect of Supplementing Chelated minerals on the performance of lactating cow. Abstr. No. 351. In Proc. VII Animal Nutrition Research Workers Conference (12-14) December Chennai, 1997.

Rafiq, M., S. Mumtaz, N. Akhtar, M. Khan (2003). Effect of strategic supplementation with multi-nutrient urea molasses blocks on body weight and body condition score of Lohi sheep owned by tenants of Pakistan. Small Ruminant Research Health Science Journal Elsevier. 70 (2-3): 200-208.

Senn, M.B. Durst, A. Kaufmann and W. Langhans. 1995. Feeding patterns of lactating cows of three different breeds fed hay, corn silage and grass silage. Physiol Behav. 58 (2): 229-236.

Sprowson, G.W. and D.H. Honess 1980. A comparison of a conventional with a complete ration system. Zimbabwe Agriculture Journal. 77: 249-52.

$\mathrm{Su}$, A.K. and R.C. Hsieh 1999. Effect of feeding total mixed ration on the lactation performance and blood parameters of dairy goats J. Tiawan Livestock Res., 32: 183-191.

Vijchulata, P.; Chanvilaikakom, D.; 
Djajanegava A. (ed.) and Sukmawati, A. 1994. Macro and micro elements in plasma and milk of dairy cows receiving concentrates with or without mineral supplements. Sustainable
Animal production and the Environment. In Proc. of the $7^{\text {th }}$ AAAP Animal Science Congress, Bali, Indonesia, 11-16 July, Vol. 2, Contributed Paper, pp. 231-232.

\section{How to cite this article:}

Vivekin Pachuari, Sushil Kumar Mishra, A.K. Tripathi and Yadav, K.S. 2019. Comparative Study of Strategic Supplementation on Enhancement of Average Milk Production of Cattle. Int.J.Curr.Microbiol.App.Sci. 8(05): 1628-1633. doi: https://doi.org/10.20546/ijcmas.2019.805.188 